\title{
The Quality of the Service, Superior Value Generator in the Restaurant Sector
}

\author{
Luis Enrique Valdez-Juárez ${ }^{1}$, Nicolas Salvador Beltramino ${ }^{2}$, Roberto Limón-Ulloa ${ }^{1} \&$ Elva Alicia \\ Ramos-Escobar ${ }^{1}$ \\ ${ }^{1}$ Technological Institute of Sonora, Department of Administrative and Economic Sciences, Obregon, Sonora, \\ México \\ ${ }^{2}$ University of Villa María, Department of Administration and Internationalization, Cordoba, Argentina \\ Correspondence: Luis Enrique Valdez-Juárez, Instituto Tecnologico de Sonora, Road to the airport Km 2, \\ Colonia San German, Zip Code 870, Zip. 85400, Guaymas Sonora, Mexico. E-mail: levaldez@itson.edu.mx
}

Received: July 19, 2019 Accepted: August 10, 2019 Online Published: August 19, 2019

doi:10.5539/ijms.v11n3p87 URL: https://doi.org/10.5539/ijms.v11n3p87

\begin{abstract}
The purpose of this study is to analyze the effects of quality service on the image and the reputation obtained in restaurants. We also analyze the effect that the business image has on the reputation of restaurants. Finally, we want to discover the mediation effect of the image between the quality service and the reputation of the restaurants. This research is based on a sample of 202 consumers of five restaurants (franchise type) in the city of Guaymas Sonora, Mexico. The data collection was conducted during the months of March to June 2016. The estimates of the relationships (hypothesis) have been tested through the System of Structural Equations based on the variance with the Partial Least Squares technique. The results show that quality in the service has a strong influence on the image of restaurants. In addition, we found that the image of the business significantly influences the reputation of restaurants. However, the service quality does not have significant effects on business reputation. We have also found that the business image is a variable that contributes to a greater significant effect between business reputation and service quality. Research contributes to the development of the literature on consumer behavior and service marketing.
\end{abstract}

Keywords: quality in the service (QS), tangible elements (TE), empathy (EM), business image (BI), business reputation (BR), small and medium enterprises (SMEs)

\section{Introduction}

With the emergence of the knowledge society and new information technologies, driven by the productive sectors and by changes in economies of scale from the era of globalization, organizations are in a voracious fight of competitiveness (Curley \& Salmelin, 2018; Drucker, 2012; Ladeur, 2017). Unlike the times in the past where the economy revolved solely around manufacturing activities, the economy at present has focused on service activities (Cano, Molina Morejon, \& Corona-Sandoval, 2018). Today, the service sector generates more than two thirds of the world's gross domestic product (GDP) and is the main source of employment in the most important economies and for emerging economies (OECD, 2017; Zahra \& Wright, 2011).

Services are defined by a large number of authors on the subject; one such definition is as follows: the actions, processes, and performances provided or produced by an entity or person for another entity or person (Parasuraman, Zeithaml, \& Berry, 1998; Thai, Tay, Tan, \& Lai, 2014). Services are also conceived as economic activities whose result is not something physical or tangible but intangible and consumed simultaneously during its production (Kim, Tang, \& Bosselman, 2018; Wallin Andreassenweight \& Lindestad, 1998). Therefore, the generation of value is associated to the sensations of the customer-consumer at that moment, generating a value or not immediately (Anker, Sparks, Moutinho, \& Grönroos, 2015; Goldstein, Johnston, Duffy, \& Rao, 2002). The theory of consumer behavior has shown that customers in modern times have become more demanding and are assessing more precisely the elements that meet their needs. These motivational factors can be imposed not only by the individual but also by the eternal motivators that normally come from other people (Arnould \& Thompson, 2005; van Doorn et al., 2010). In addition to these factors, the theory of service marketing has explained that consumer behavior considers the external factors (social, political, cultural, and technological), which are determining factors for the processing of data in the evaluation to make the decision of purchase (personal, 
psychological, and sociological factors) in the choice of good or service and in the post-purchase (Kotler, Armstrong, \& Parment, 2016; Yi, 2018a). It is evident that in these times, consumers have been valuing with greater emphasis the tangible aspects of the companies, such as the functional facilities (layout), the comfort of the furniture (ergonomics), the appearance of the employees, the design of the product, and the physical infrastructure of the business (technology), among other factors that set the appearance of the place and that affect the quality of service, image, and corporate reputation (Ariffin, Bibon, \& Abdullah, 2012; Wang \& Emurian, 2005). With the increasing demands of consumers, organizations are adopting new marketing strategies focused on innovation (Waheed et al., 2018). These strategies are derived from an exhaustive analysis of the market and consumer behavior to meet their current needs and future desires (Lusch, Vargo, Bolton, \& Webster, 2014; Teece, 2010; Vargo, Lusch, \& Lusch, 2014). In addition, with these exponential changes in the market, organizations focused on the presentation of services are resorting to sustainable marketing strategies to ensure sustained growth through corporate social responsibility (French, 2015; Jayanti \& Rajeev Gowda, 2014; Quoquab, Thurasamy, \& Mohammad, 2017; Spence, 2016).

As in other countries, in Mexico, the services sector is one of the pillars that sustain the economy. The restaurant industry's proportion of the gross domestic product (GDP) is 1.6\%; in addition, with the generation of 1.5 million jobs, it contributes $6.6 \%$ of total jobs (Cano et al., 2018; Flores, Castillo, \& Rodríguez, 2013). Mexico is known worldwide for its great gastronomic diversity and the warmth of its citizens. These manifestations have been gestated since ancient times, due to the different social and political stages that the country has gone through. With these changes and the arrival of other cultures (Spanish and North American), the Mexican dishes offered in the restaurants have multiplied and improved. Furthermore, with the signing of the free trade agreement between Mexico, the United States of America, and Canada in 1994, the arrival and proliferation of large franchise chain restaurants began (Khan, 2014; Lanchimba \& Medina, 2018; Sun, Park, \& He, 2019). With this, a new change in consumer behavior begins to take shape (modifying the purchasing behavior of customers), creating new business opportunities for local entrepreneurs (Alon, 2006; Madanoglu, Alon, \& Shoham, 2017). However, this type of multinational company affects domestic businesses mainly because of the following: 1) lower market share, 2) more demanding market segments, and 3) lower profits (Estrin, Nielsen, \& Nielsen, 2017; Song, Park, \& Lee, 2017; John Williams, 1998). In addition, these businesses have been developing strategies targeting creating long-term relationships with customers to generate brand loyalty, enhance their reputation, and improve profitability (Ashraf, Ilyas, Imtiaz, \& Ahmad, 2018; Balmer \& Greyser, 2006; Fracarolli Nunes \& Lee Park, 2017). However, despite these efforts, this type of business has strong limitations on being more competitive. The following are among the main challenges: (1) less automated processes, (2) certified quality processes, (3) the co-specialization of its personnel, (4) the focus on day-to-day activities, and (5) an organizational structure in vertical form (Chen \& Elston, 2013; Jogaratnam, 2017; Khalique, Isa, Shaari, Abdul, \& Ageel, 2011).

Although there are studies on the development of the gastronomic market, a large portion of them have focused on large chains and mainly on the construction of the brand based on the quality of the service. However, studies on small regional enterprises are scarce (Villegas-Malagón, Reyes-Martínez, Reyes, García, Garcia, \& Pérez-Mora, 2017). Although, in recent years, there has been an increase in studies of this type that analyze the behavior of the perception of the quality of services in different regions, even this field of action is not fully developed (Cano et al., 2018; Flores et al., 2013; Han \& Hyun, 2017; Madanoglu et al., 2008; Villegas-Malagón et al., 2017). The study contributes to the literature on Consumer Behavior and Marketing Service through two ways. First, the study contributes by providing theoretical and empirical evidence on the evaluation of quality in the service of franchise-type restaurants established in the region of an emerging country, through analysis the tangible and intangible factors that the consumer values the most. Second, an important theoretical and empirical contribution is made through the analysis of total customer satisfaction, incorporating the image and business reputation into the traditional SERVQUAL model. These dimensions (image and business reputation) are part of the theory of Marketing Service, which strengthens the theoretical model structured in the investigation.

In the work, three main objectives have been contemplated, derived from the perception of the quality of the service of the consumers. The first one analyzes the effects of quality service on the image and the reputation obtained in restaurants. In the second, we analyze the effect that the business image has on the reputation of restaurants. Third, we analyze the mediation effect of the image between the quality service and the reputation of the restaurants. This article has the following structure. The first part presents the literature review, the empirical review, and the development of the hypotheses. Second, the methodology used, the sample, and its characteristics are explained. In addition, the justification of the variables under study is described, and the results, discussions, and conclusions of the investigation are shown in the final section. 


\section{Literature and Development of Hypothesis}

\subsection{Quality of Service in Organizations}

The issue of quality in the service for organizations has been one of the main challenges since very remote times. Therefore, specialists in business administration are constantly analyzing this element that generates competitiveness and quality (Dubey et al., 2018; Thai et al., 2014). The concept of quality in the service may have variations in the existing literature. Therefore, it is important to explain that quality can be conceptualized as the current and future satisfaction of customers (consumers) of an organization through its products and services with zero defects and/or zero errors (Deming, 2000; Deming \& Orsini, 2013; Thai et al., 2014). The main theories that address the issue of quality in the service are based on the information that originated from the main founders, such as Joseph Juran, Philip Krosby, Kouru Ishikawa, and mainly, Edward Deming. This knowledge harkens to events that occurred during and after the industrial revolution (Hackman \& Wageman, 1995; Kiran, 2016). These contributions have prevailed until currently; from these, necessary and decisive actions to achieve total customer satisfaction are highlighted (Kiran, 2016; Rungtusanatham, Ogden, \& Wu, 2003). Therefore, a large number of innovative companies are adopting strategies that lead them to meet the needs of customers through the adoption of total quality management and new marketing strategies based on the analysis of consumer behavior (Kotler et al., 2016; Teece, 2010). According to Kotler et al. (2016) and Yi, (2018b), consumer behavior is a process in which individuals make conscious decisions to acquire a product and/or service to satisfy their needs and desires. This theory analyzes the consumer from various perspectives, from an economic point of view, the consumer is seen as a rational being because he first analyzes the price of the good and/or service acquired to satisfy his needs (Oliver, 2014; Zhu, Freeman, \& Cavusgil, 2018). From the perspective of learning, decision making for the acquisition of goods and/or services is based on past experiences (in the repetition) (Walls, Okumus, Wang, \& Kwun, 2011). Other factors related to consumer behavior, according to Holbrook and Hirschman (1982), Inkeles (2017) and Sánchez-Fernández, Iniesta-Bonillo and Holbrook (2018), are the psychoanalytic and sociological, which are divided into internal and external, such as friendship and socialization, these are known as internal impulses that encourage the consumer to acquire goods and/or services in a non-existent way rational (influence of reference groups).

In addition to this classic theory centered on the product and the client, the theory related to the marketing of services arises, which, in addition to contemplating product, service, and client variables, high value strategies are added. These strategies include a close relationship with the customer, added value and digital tools for the full satisfaction of consumers, and the discovery of new demands and desires of potential customers (Grönroos, 1984; Ndubisi, Nataraajan, \& Lai, 2014; Palmatier, Dant, Grewal, \& Evans, 2006). Thus, companies focus on the following essential characteristics of a service: intangibility, inseparability, and variability. In the review of the literature, we have discovered that most of the theorists and experts in the field of consumer behavior and quality service have used the SERVQUAL model to measure consumer perception in the restaurant industry (Barroso, Carrión, \& Roldán, 2010; Kang \& James, 2004). The model analyzes the customer's perception based on the satisfaction evaluation (expected) in the final delivery of the service offered by the company. These expectations and consumer needs are measured through an instrument that includes 22 items (Cronin \& Taylor, 1992; Fukey, Issac, Balasubramanian, \& Jaykumar, 2014; Oliver, 2014). This model was developed by experts from the North American school (Parasuraman, Zeithaml, \& Berry, 1988; Parasuraman et al., 1998). This model includes the following dimensions: (1) tangible elements: physical facilities, equipment, and the appearance of employees; (2) reliability: ability to perform the promised service reliably and precise; (3) responsiveness: provision to help customers and offer faster service; (4) assurance: knowledge and courtesy of employees and their ability to inspire confidence and security; and (5) empathy: care in the individualized attention for each client.

\subsection{Quality in Service in the Image and Reputation of the Company}

Service quality has been a recurrent, difficult, and expensive subject to maintain for most organizations. This finding is mainly because the market and the components that satisfy the customer (consumer) have evolved, and the demands are increasingly high (Anker et al., 2015; Chen, 2015; Grönroos \& Gummerus, 2014). From the perspective of the theory of consumer behavior and service marketing, quality in the service has become a strategy that generates the following for a company: competitiveness, economic growth, market positioning, image, and reputation (Martínez \& Martínez, 2010; Storbacka, Strandvik, \& Grönroos, 1994; Suwandej, 2015). The image is conceived as the set of beliefs, ideas, and perceptions that a person has about an object or an organization (Kotler et al., 2016). Reputation is known as the total perception of customers-consumers about the company and is related to experiences, expected expectations and perceived value (de Leaniz \& del Bosque-Rodríguez, 2016; Foroudi, 2019). These two concepts (image and corporate reputation) can be classified into functional (tangible) and emotional (intangible) elements, which influence consumer behavior, brand positioning, and total customer 
satisfaction (Melewar, Foroudi, Gupta, Kitchen, \& Foroudi, 2017; van den Bosch, Elving, \& de Jong, 2006). Several empirical studies have concluded that the companies that provide services based on the satisfaction of the demands of the clients and to understand with greater certainty the behavior of the consumer, have managed to establish long-term relationships, improve the products and the services through strategies effective marketing that help enhance the image and corporate reputation (Iglesias, Markovic, Singh, \& Sierra, 2019; Tsai \& Wang, 2017). Thus, the company is viewed as a reliable, quality business, and the reputation is increased (Han et al., 2015; Nyadzayo \& Khajehzadeh, 2016). However, this finding cannot be achieved without the commitment and loyalty of the leaders and collaborators of the organization (Chen, 2015; Susanti, 2013). Some authors have explained that, for the perception of quality of service in fast food restaurants, consumers require more attention, speed, product quality, and affordable prices (Madanoglu et al., 2008; McKenzie-Mohr \& Schultz, 2014; Namin, 2017; Zhang et al., 2019). These businesses have been gaining ground in highly competitive markets. The success is based on creative and innovative business models (comfortable facilities, adoption of technologies, and commitment of employees) that guarantee the basic requirements of the consumer (Ahn \& Seo, 2018; Kim et al., 2018). These actions have led restaurant companies to increase their sales, improve customer satisfaction, increase customer loyalty, rapidly position and actively participate in improving their reputation (de Leaniz \& del Bosque Rodríguez, 2016; Namin, 2017; Yaman, 2018). These organizational and financial results are originated by the correct management of the quality of the service and that consequently are reflected in the increase of the image and reputation of the businesses dedicated to the service of restaurants (Sanchez-Franco, Cepeda-Carrion, \& Roldán, 2019). From the above, we have developed the following hypotheses:

\section{H1. A greater focus on quality actions in the service increases the image of restaurants.}

\section{H2. A greater focus on quality actions in the service increases the reputation of restaurants.}

\subsection{The Image and the Business Reputation}

In the context of the theory of consumer behavior and service marketing, experts in the field have shown that image and business reputation are closely related and that they significantly influence total consumer satisfaction (Grönroos \& Gummerus, 2014; Zhang, 2015). The image is visualized as the set of attributes, factors and elements with which a company must satisfy the needs of the consumer (Gray \& Balmer, 1998; Nguyen \& Leblanc, 2001; Veloutsou \& Delgado-Ballester, 2018). These results are the product of the specific actions of the organization that are valued by the customer-consumer and which are transformed into the reputation of the business (Barnett, Jermier, \& Lafferty, 2006; Gotsi \& Wilson, 2001). Studies that relate to the image and the business reputation in function to the quality in the service have concluded that these variables are determinants for the growth and competitiveness of service companies (Chun, 2005; de Leaniz \& del Bosque Rodríguez, 2016; C. Wang, Hoegg, \& Dahl, 2018). Recent studies on consumer behavior have stated that the image is a key element that generates greater consumer loyalty and with this the companies have experienced an increase in their reputation (Elsäßer \& Wirtz, 2017; Heinberg, Ozkaya, \& Taube, 2018a; Kim, Kim, \& Byoungsoo, 2018). These results are derived from the tangible and intangible elements that the company provides its customers (quality products, variety of products, self-service, reasonable prices, security of the facilities and the use of new technologies in the processes), that are reflected in the image increase and that consolidates the business reputation (Erkmen \& Hancer, 2019; Heinberg, Ozkaya, \& Taube, 2018b). However, other researchers such as Fracarolli Nunes and Lee Park (2017) and Lee, Lim, and Drumwright (2018) note that the image is built with marketing strategies (online and promotional) and with actions of quality in the service, which are factors that momentarily solidify the reputation of the business. This finding is because some businesses do not execute these strategies when the business is created but instead do so after a crisis or adverse experiences with client dissatisfaction. In addition, several recent studies from different regions focused on service quality, have confirmed that when companies invest in strengthening their brand, their corporate identity and improving a better image, customer satisfaction can be increased and this leads them to increase the reputation within the market in the sector in which it competes (Escrig-Tena, Garcia-Juan, \& Segarra-Ciprés, 2019; Wu, Cheng, Ai, \& Chen, 2019). From the above, we have structured the following hypothesis:

\section{H3. A greater business image increases the reputation level of restaurants}




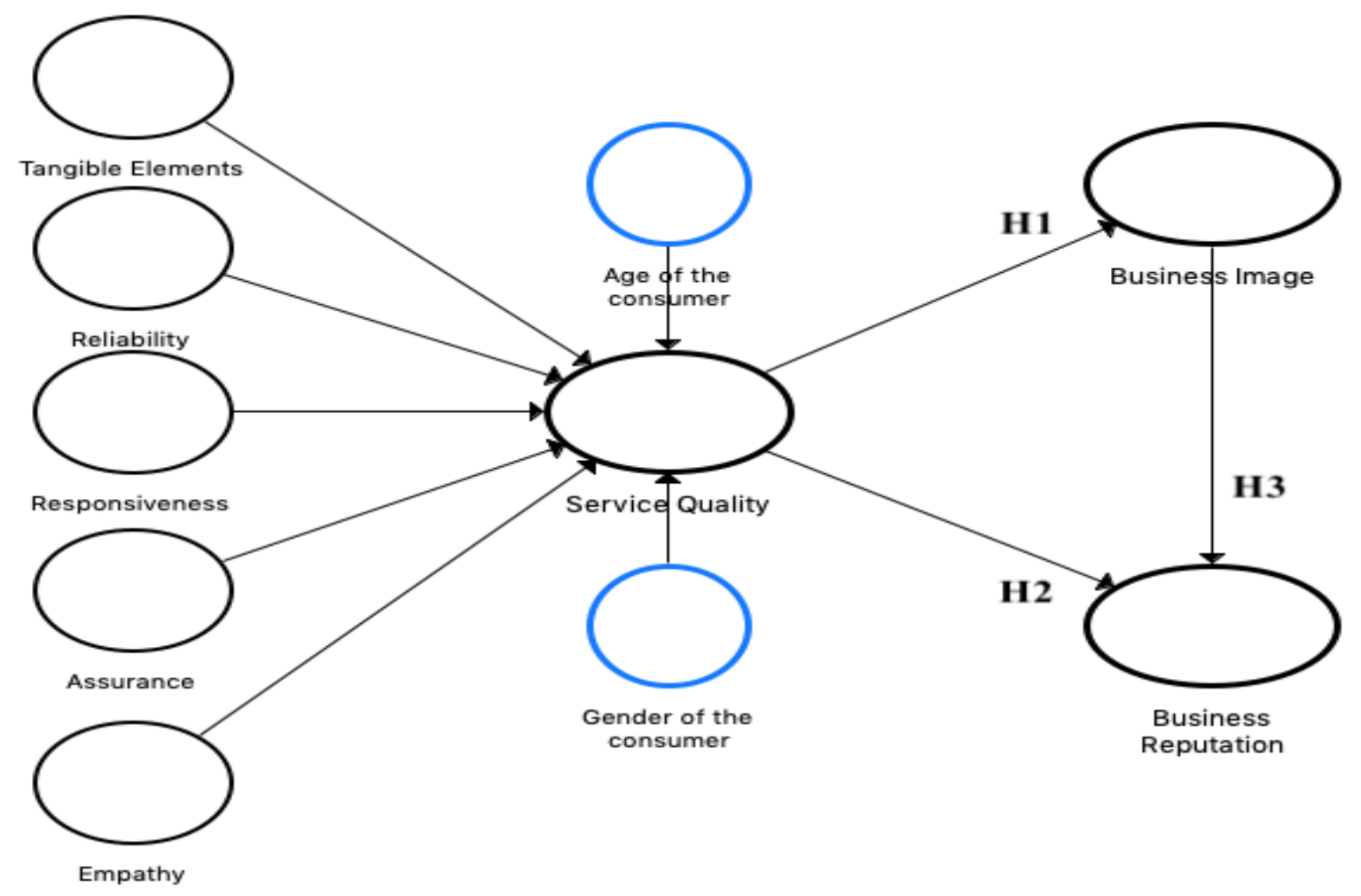

Figure 1. Theoretical model of research

\section{Research Methods}

The structure of the sample is based on the principles of stratified sampling for finite populations. The population is composed of consumers of the main restaurants established in the city of Guaymas Sonora, Mexico. The city has around 200 thousand citizens, is located geographically in the Northwest of Mexico and exists at a distance of 400 kilometers from the border line of the United States of North America. This proximity has greatly influenced the development of restaurant franchises in this region of the country. In the Guaymas region there are a total of 80 establishments dedicated to food service (INEGI, 2018). However, most are small businesses and are not franchised. For our study, we have selected the 5 most visited franchise restaurants in the city by young people and young adults (25 to 45 years) (Lockers Sports, Toscano's, Diego's, Chiltepinos Wings and City Salads), these subjects represent $8.9 \%$ of the total population. The main characteristic of these businesses is that they are franchised, their market is regional, and they also have financial capital of Mexican origin. To obtain the information of the consumers about the perception of the quality of the service, the image, and the reputation of the business, authorization was requested to the manager of each of the restaurants that participate in the investigation. The investigation is of exploratory and predictive type, for the determination of the sample, due to the characteristics of the selected consumers (population), to the nature and to the objectives of the investigation, the sampling technique chosen is of non-probabilistic type and/or directed (Hair, 2010). The technique for collecting the information was through a personal interview (questionnaire) self-directed to the consumer. To obtain more accurate data and with greater objectivity, the interview was conducted after having experienced and paid for the service. Before carrying out the field work, a pilot test was launched with $10 \%$ of the total sample, in order to validate the contents of the instrument and rule out any anomaly. The field work for the data collection was conducted during the months of March to June of 2016. Clients who did not want to participate in the survey were replaced by other people with the same characteristics. The responses of the clients that responded in the first round of interviews ( $80 \%$ of the sample) were compared with those that responded by replacement ( $20 \%$ of the sample). No significant differences between the two groups emerged from the variables considered, using $t$ tests and chi-square tests. In addition, common method variance (CMV) bias was analyzed, since the data came from a single source of information through a single questionnaire. It is possible that the relationships between the variables were inflated as a consequence of CMV. To identify the existence of such bias, we used Harman's single-factor test, as suggested by Reio (2010). The variance explained by the factors in our study is over $60.97 \%$. The three constructs of our theoretical model are clearly identified in factor analysis 
(KMO: 0.942; Bartlett sphericity test 0.000). These results all suggest that the common method bias was not a big concern in our study. Finally, a sample of 202 perceptions of the selected consumers was divided equally among the 5 restaurants that participated in the study; this number of clients represents $72.6 \%$ of the total sample. The composition and characteristics of the sample can be observed in Tables 1 and 2.

Table 1. Population and sample

\begin{tabular}{lll}
\hline Data & & Conversion \\
\hline $\mathbf{N}$ & 22,350 & Total population \\
$\mathbf{p}$ & $50 \%$ & 0.50 \\
$\mathbf{q}$ & $50 \%$ & 0.50 \\
$\boldsymbol{\delta}$ & $95 \%$ & 1.96 \\
$\mathbf{e}$ & $5 \%$ & 0.05 \\
$\mathbf{n}$ & 378 & Total sample
\end{tabular}

Note: $\mathrm{N}=$ population, $\mathrm{p}=$ probability in favor, $\mathrm{q}=$ probability against, $\delta=$ confidence coefficient, $\mathrm{e}=$ estimation error, $\mathrm{n}=$ total $\mathrm{sample}$.

Table 2. Gender and schooling

\begin{tabular}{llllllll}
\hline Gender & Total & Youth & Mature youth & Percentage & Basic education & University education & $\%$ total \\
\hline Male & 103 & $86.4 \%$ & $13.6 \%$ & $49.0 \%$ & $56.3 \%$ & $43.7 \%$ & 100.0 \\
Female & 99 & $80.8 \%$ & $19.2 \%$ & $51.0 \%$ & $50.5 \%$ & $49.5 \%$ & 100.0 \\
\hline
\end{tabular}

Note: Youth $=$ age of 25 to 35 years, Mature youth = age of 36 to 45 years.

\subsection{Measurement of the Variables}

Quality in the service. The literature has exposed that this variable has its origin in the theory of consumer behavior and in the marketing of services; currently, it contemplates the total satisfaction of the clients and the consumers derived from the products and services that an organization offers (Nwachukv, Vitell, Gilbert, \& Barnes, 1997; Rungtusanatham et al., 2003; Sanclemente-Téllez, 2017). This strategy, which is focused on customer satisfaction, is related to business results, such as image, reputation, and the increase in financial profitability. From this theoretical and empirical review, customers of the franchise type restaurants have been requested to respond to the 21 questions in the survey that are measured on a Likert scale of 5 points $(1$, total disagreement; 5 , total agreement). For the measurement of this variable, we have used the SERVQUAL model developed by Parasuraman, Zeithaml, and Berry (1988), as a reference. After consideration, our study includes the following dimensions: (1) tangible elements, (2) reliability, (3) responsiveness, (4) assurance, and (5) empathy (see Table 3). 
Table 3. Internal consistency and convergent validity by construct (Formative-Second order)

\begin{tabular}{|c|c|c|c|}
\hline Variable (Quality in the service) & Weight & VIF & Value $\mathrm{t}$ \\
\hline \multicolumn{4}{|l|}{ The company and its staff... } \\
\hline \multicolumn{4}{|l|}{ Tangible elements } \\
\hline It has moderate and equipped facilities & $0.436 * * *$ & 1.919 & 3.038 \\
\hline It has new technologies & $0.245 * * *$ & 2.048 & 6.084 \\
\hline Employees project a good image & $0.204 * * *$ & 1.497 & 12.100 \\
\hline Brochures, receipts, invoice, and advertising are attractive & $0.360 * * *$ & 1.349 & 6.463 \\
\hline \multicolumn{4}{|l|}{ Reliability } \\
\hline Comply with deliveries on time & $0.491 * * *$ & 2.581 & 5.057 \\
\hline Comply with the demands of the client & $0.202 * * *$ & 2.292 & 4.886 \\
\hline Solve customer problems & $0.301 * * *$ & 2.523 & 2.186 \\
\hline Provide quality service without making mistakes & $0.141 * * *$ & 2.332 & 3.018 \\
\hline \multicolumn{4}{|l|}{ Responsiveness } \\
\hline Complies with invoice delivery on time & $0.208 * * *$ & 2.307 & 3.658 \\
\hline It is oriented to solve the customer's concerns & $0.211 * * *$ & 2.243 & 3.287 \\
\hline It is always available to the client & $0.264 * * *$ & 2.529 & 2.210 \\
\hline Always help the customer at all times & $0.453 * * *$ & 2.768 & 4.251 \\
\hline \multicolumn{4}{|l|}{ Assurance } \\
\hline Inspire customer confidence & $0.272 * * *$ & 2.500 & 2.949 \\
\hline Shows friendliness with the client & $0.366^{* * *}$ & 2.804 & 3.729 \\
\hline The documentation issued by the company is reliable & $0.247 * * *$ & 2.965 & 4.909 \\
\hline They are trained in solving customer problems & $0.276^{* * *}$ & 2.638 & 3.684 \\
\hline \multicolumn{4}{|l|}{ Empathy } \\
\hline Offers personalized attention to the client & $0.319 * * *$ & 2.856 & 3.737 \\
\hline It addresses the interests of the client & $0.113^{* * *}$ & 2.282 & 2.708 \\
\hline The schedules are suitable for customer service & $0.100 * * *$ & 3.209 & 2.323 \\
\hline It has enough staff to serve the client & $0.341 * * *$ & 3.264 & 3.789 \\
\hline It is committed to cover all the needs of the client & $0.258 * * *$ & 2.950 & 2.238 \\
\hline
\end{tabular}

Note: $*: \mathrm{p}<0.1, * *: \mathrm{p}<0.05, * * *: \mathrm{p}<0.01$.

Business Image. This variable was measured based on the theory of service marketing and models related to the quality of service, which include the perception of consumers of the business image. The questionnaire collects responses from consumers of franchise-type restaurants on the degree of perception regarding the business image. Thus, a scale (5-point Likert type, with 1, completely disagree and 5, completely agree) was used. For the measurement of this variable, the studies by Kang and James (2004) and Thai et al. (2014) were considered; the questionnaire is composed of 3 questions, which can be observed in Table 4 .

Table 4. Internal consistency and convergent validity by construct (reflective-first order)

\begin{tabular}{llll}
\hline Variable & FL & CR & AC \\
\hline Business Image: & & 0.777 & 0.601 \\
It is a creative and innovative company & $0.747^{* * *}$ & & \\
It is a reliable company & $0.676^{* * *}$ & & \\
It is an efficient company & $0.775^{* * *}$ & & \\
\hline
\end{tabular}

Note: $\mathrm{FL}=$ Factor load, $\mathrm{CR}=$ Composite Reliability, $\mathrm{AC}=$ Cronbach's Alpha, $*$ : $\mathrm{p}<0.1,{ }^{* *}: \mathrm{p}<0.05,{ }^{* * *}: \mathrm{p}<0.01$.

Business Reputation. In the literature, there is a record of a large number of empirical and conceptual studies to measure business reputation. For our study, we have considered the theory of the marketing of services and the valuation of the consumer regarding the perception that it has on the reputation of the business; this is an output of the perceived quality of the service and of the appreciation of the business image (Fukey et al., 2014; Kiran, 2016; Wallin Andreassenweight \& Lindestad, 1998). In the questionnaire review that was conducted, consumers of the franchise-type restaurants were asked to answer the questions that rate the level of perception of this variable. This variable was measured by three questions, referencing the studies developed by Wallin Andreassen and Lindestad (1998), Nguyen and Leblanc (2001) and Walsh, Beatty, and Shiu, (2009). For this review, a Likert scale of 5 points was used with 1 , completely disagree and 5 , completely agree, see Table 5 . 
Table 5. Internal consistency and convergent validity by construct (reflective first order)

\begin{tabular}{llll}
\hline Variable & FL & CR & AC \\
\hline Business Reputation & & 0.838 & 0.714 \\
It is a respected company & $0.830^{* * *}$ & & \\
It is a prestigious company & $0.801^{* * *}$ & & \\
It is a recognized company & $0.755^{* * *}$ & & \\
\hline CR, composite reliability; AC, Cronbach's alpha, *: $\mathrm{p}<0.1, * *: \mathrm{p}<0.05, * * *$ & $\mathrm{p}<0.01$.
\end{tabular}

Note: FL, factor load; CR, composite reliability; AC, Cronbach's alpha, *: $\mathrm{p}<0.1, * *: \mathrm{p}<0.05, * * *: \mathrm{p}<0.01$.

\subsection{Control Variables}

Gender of the respondent. To measure this variable, it was classified, and a value was assigned to each classification. For the female, the value of 0 was granted, and for the male, the value of 1 was granted. The age of the respondent was granted a value. To measure this variable and incorporate it into the theoretical model, we have segmented the ages of consumers. The remainings are as follows: youth (age, 25 to 35 years), mature youth (age, 36 to 45 years); see Table 2 .

\section{Results}

\subsection{Measurement Model}

The variable of formative type (Service Quality) in mode B was evaluated through the value of the weights of each item and its significance. In addition, the value of the variation inflation factor (VIF) was analyzed. The results of the analysis show that the values of the weights are significant and that, in addition, the value of the VIF is below 5 as recommended by Hair, Jr., Sarstedt, and Ringle (2017). With this, the presence of multicollinearity between the indicators is discarded (see Table 2 and Figure 2). To evaluate the measurement model with reflective type variables in A mode (image and business reputation), the composite reliability of each item, the internal consistency of the scale, and the convergent validity are analyzed. To measure the relationship and the individual reliability of each item, a standardized load on the factor greater than 0.707 is recommended (Carmines \& Zeller, 1991; Chin \& Dibbern, 2010; Roberts, Priest, \& Traynor, 2006). Our results lie in a range between 0.676 and 0.830, which is close to and above 0.707 , respectively. In our model, we have decided to include the value with a load of 0.677 for the following reasons: (1) It is significant at a level of 0.001 ; (2) It is very close to the acceptable threshold of 0.707 ; (3) This item is important to conserving the construct validity (Wang, Chen, \& Benitez-Amado, 2015). The composite reliability shows values ranging from 0.777 to 0.838 , thus fulfilling the requirement that the indicator should be close to the value of 0.800 for basic research, as proposed by Nunnally (1978) and Vandenberg and Lance (2000). Cronbach's alpha is considered satisfactory over 0.700 (Hair, Black, Babin, Anderson, \& Tatham, 2006) for mature studies; for studies in the initial phase, a value of 0.600 is sufficient (Cronbach, 1951; Gliem \& Gliem, 2003; Peterson, 1994). Our results have values between 0.601 and 0.714 , demonstrating an acceptable reliability of the construct (see Table 3 and 4, and Figure 2). 


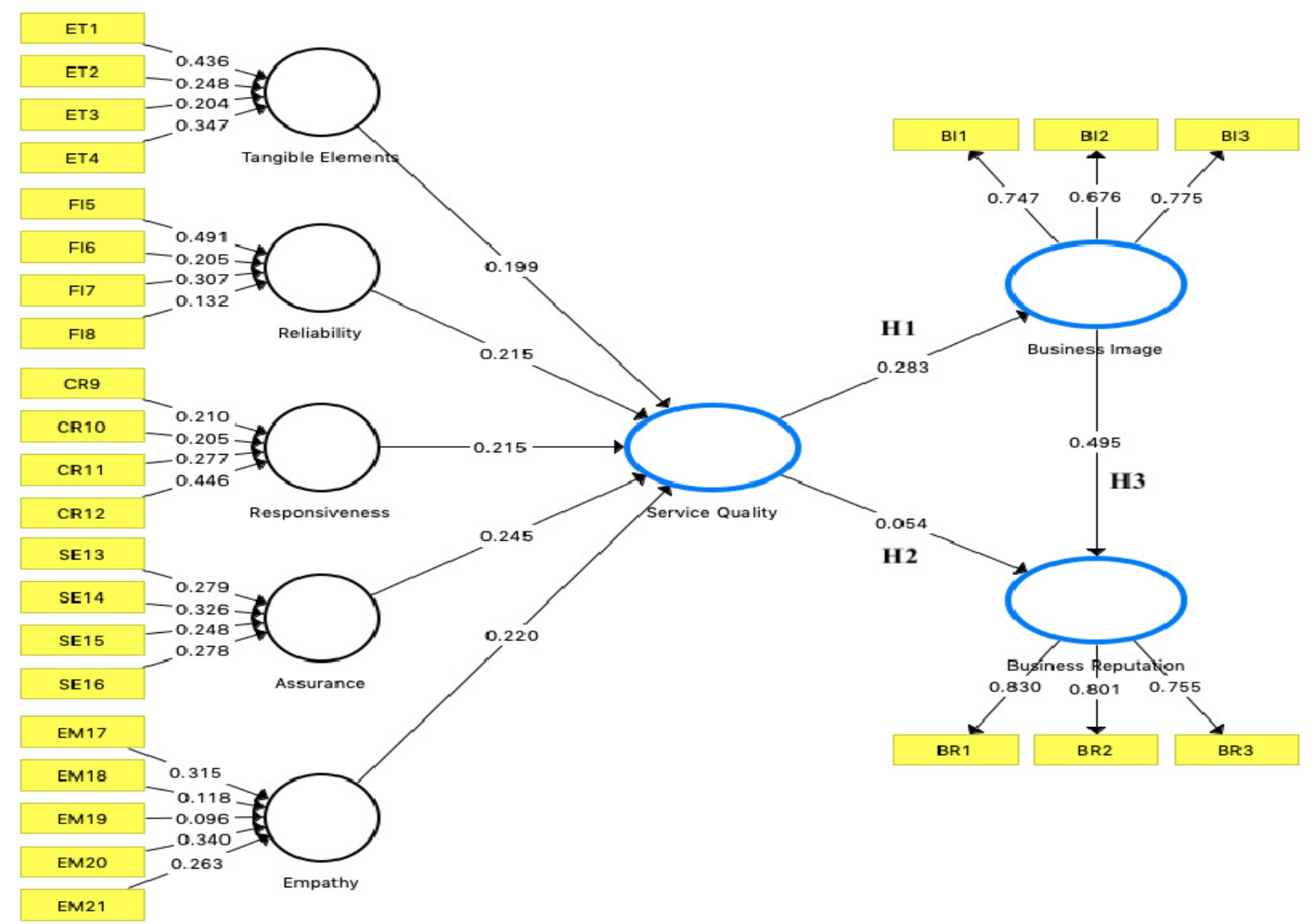

Figure 2. Theoretical model of research

Note: Internal consistency and convergent validity by construct (smartpls output).

The average variance extracted (AVE) indicates the average amount of the variance explained by the indicators of the construct. Our AVE values are 0.539, 0.628, and 0.633. These results are above the threshold of 0.500, as proposed by Hair Jr, Black, Babin, Anderson, and Tatham (2010). Finally, the discriminant validity of the constructions in the model was verified by analyzing the square root of the AVE. The (diagonal) results of the vertical and horizontal AVE are below the correlation between the constructs. This test detects no anomaly (see Table 6). Our results provide adequate validity and reliability (convergent and discriminant).

Table 6. Discriminant validity of the theoretical model

\begin{tabular}{lllll}
\hline Variable & AVE & SQ & BI & BR \\
\hline SQ & 0.628 & 0.792 & & \\
BI & 0.539 & 0.282 & 0.734 & \\
BR & 0.633 & 0.189 & 0.510 & 0.796 \\
\hline
\end{tabular}

Note: AVE, average variance extracted; SQ, service quality; BI, business image; BR, business reputation.

Table 7. Results of the hypothesis test

\begin{tabular}{llllll}
\hline Hypothesis & Beta Value & T Score & P Valor & F2 & Confirmed/Rejected \\
\hline H1. SQ -> BI & $0.282^{* * *}$ & 3.668 & 0.000 & 0.086 & Confirmed \\
H2. SQ-> BR & 0.050 & 0.068 & 0.468 & 0.003 & Rejected \\
H3. BI-> BR & $0.496^{* * *}$ & 8.252 & 0.000 & 0.306 & Confirmed \\
\hline
\end{tabular}

Table 7 shows the results of the estimation with PLS. We find empirical support for the hypotheses (H1 and H3) that have been structured in the model. The results of the hypotheses (H1 and H3) have significant and positive effects. This finding indicates that the quality in the service has a strong relationship with the business image, according to the beta value of $0.282 * * *$. H3 presents this same behavior, where the business image variable 
significantly and positively influences the reputation of the SME restaurants, according to the beta value of 0.496 ***. In addition, we have discovered that $\mathrm{H} 2$, on the relationship between quality in the service and business reputation, has no significant effects, according to the value of beta, 0.050 , and the $p$ value of 0.468 . From the previous analysis, we report that $\mathrm{H} 2$ has been rejected because it does not have empirical support. Finally, we have examined the effect of the control variables: the age and gender of the consumer surveyed and the relationship that the consumer has with the quality of the service. The results indicate that these variables do not have a significant influence on the quality of service in SME restaurants, according to the following values: $(\beta=-0.055$, p value $0.441)$ and $(\beta=-0.069$, $p$ value 0.322$)$.

To evaluate the fit of the model, the SEM techniques are based on the covariance; in PLS, it is not possible to estimate these measurements. However, PLS analyzes the value of the trajectory coefficients, the analysis of $R^{2}$, and the values of $F^{2}$; these are significant individual measures to explain the predictive capacity of the structural model (Chin \& Dibbern, 2010). The trajectory coefficients around 0.2 are considered economically significant (refer to Table 7). The analysis of the explained variance and the prediction quality of the model are measured through the value of R2. The value of F2 measures and provides the size of the effect introduced in the model; the values are shown in Table 7. The statistical test Q2 (cross-validated redundancy index) is used to evaluate and test the predictive relevance of endogenous constructs in a structured model with reflective variables. The model was evaluated through the blindfolding technique (Sarstedt, Ringle, \& Hair, 2017). Values greater than 0 show a remarkable predictive quality (Hair, 2016); the data can be observed in Table 8. In summary, we can confirm that this analysis provides an excellent predictive and explanatory capacity of the model. To explain the predictive effect of our model more accurately, we have added a goodness-of-fit test performed by PLS. Thus, we have used the standardized indicator of the residual quadratic mean (SRMR); when this value is in a range of $(<0.08-0.1)$, there is an acceptable adjustment (Henseler et al., 2014). Our result of 0.077 confirms that the proposed model has an acceptable predictive quality and demonstrates that the empirical results are aligned with the theory.

Table 8. Predictive quality and fit of the model

\begin{tabular}{lll}
\hline Variable & $\mathrm{R} 2$ & $\mathrm{Q} 2$ \\
\hline Business Image & 0.055 & 0.036 \\
Business Reputation & 0.275 & 0.147 \\
\hline
\end{tabular}

Additionally, we conducted a mediation analysis to test the mediating effect of the company's image between service quality and business reputation. According to Hayes and Scharkow (2013), they recommend doing this analysis through: (1) bias-corrected bootstrap CI and (2) the boostrap CI, these two techniques are two of the most reliable tests in this type of analysis. For this purpose, the test implies in the first moment estimating the importance of the direct effect ( $\left.c^{\prime}\right)$. In addition, two steps are subsequently carried out: (1) the determination of the indirect effects $(\mathrm{a} 1 \times \mathrm{b} 1)$ through the boostrapping technique with 5000 samples, with calculations of $90 \%$ confidence intervals (Nitzl, Roldan, \& Cepeda, 2016; Williams \& MacKinnon, 2008). (2) Second, the type of effect and the magnitude of the indirect effects in relation to the total effect are determined, to obtain the relevance or not of the direct and indirect effects and the type of mediation between the variables (Carrión, Nitzl, \& Roldán, 2017; Hair, Sarstedt, Hopkins, \& Kuppelwieser, 2014). For this purpose, the variance accounted for (VAF) index is evaluated (Hair, Hult, Ringle, Sarstedt, \& Thiele, 2017). According to Hair, Hult, Ringle, Sarstedt, and Thiele (2017) and Carrión et al. (2017), it indicates that there is partial competitive mediation when: (1) the value of (c') and all other relationships are significant, (2) when all relationships have a positive direction, and (3) when the value of the VAF is between $20 \%$ and $80 \%$. In our research, there is a partial competitive mediation according to the results obtained and the VAF value of $20.44 \%$ (see Table 9). The hypotheses developed to verify the mediating effect are:

$\mathrm{H} 1$ : The SQ, is positively directly related to the business reputation.

$\mathrm{H} 2$ : The relationship between the $\mathrm{SQ}$ and the $\mathrm{BR}$ is mediated positively by the business image.

Where $\mathrm{H} 1=\mathrm{SQ} \rightarrow \mathrm{BR}=c^{\prime}, \mathrm{H} 2=\mathrm{SQ} \rightarrow \mathrm{BR} \rightarrow \mathrm{RBR}=\mathrm{a}_{1} \times \mathrm{b}_{1}$ 
Table 9. Mediation effect

\begin{tabular}{lllllll}
\hline & Coefficient & \multicolumn{2}{l}{ Booststrap 90\% CI } & \\
\cline { 3 - 6 } & & Percentile & & & \\
\hline Direct effects & & & & & \\
$\mathrm{H}_{1}: \mathrm{c}$ & $0.401^{\text {sig }}$ & 0.242 & 0.483 & 0.276 & 0.310 & \\
$\mathrm{a}_{1}$ & $0.386^{\text {sig }}$ & 0.331 & 0.560 & 0.267 & 0.203 & \\
$\mathrm{~b}_{2}$ & $0.266^{\text {sig }}$ & 0.166 & 0.456 & 0.113 & 0.061 & \\
Indirect effects & Point estimate & Percentile & & BC & & VAF \\
$\mathrm{H}_{2}: \mathrm{a}_{1} \times \mathrm{b}_{1}$ & $0.103^{\text {sig }}$ & 0.055 & 0.255 & 0.030 & 0.012 & $20.44 \%$ \\
Total indirect effect & $0.103^{\text {sig }}$ & & & & & \\
\hline
\end{tabular}

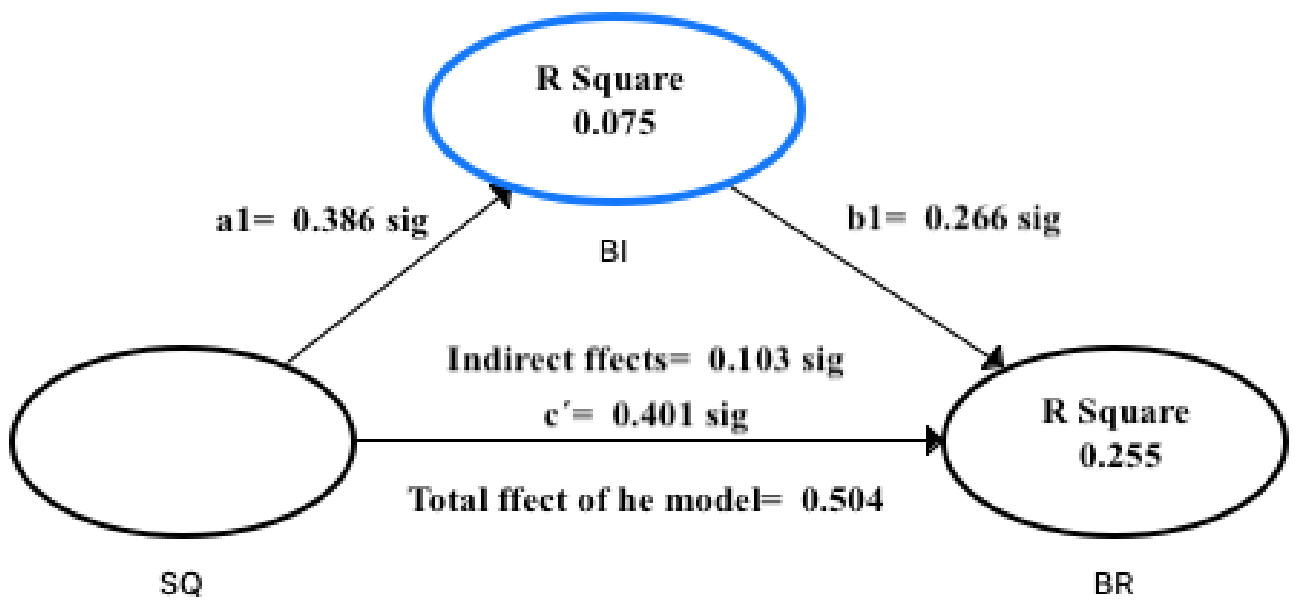

Figure 2. Model effect mediation

The results show that the variable SQ has a significant direct effect on the variable BR (H1: c ') of 0.401 Sig. (see Table 9 and Figure 2). On the other hand, all the indirect effects of the variable of mediation BI are positive and significant. This means that the $\mathrm{H} 2$ has been compatible. Therefore, variable BI positively mediates the relationship between SQ and BR $\left(\mathrm{H}_{2}: \mathrm{a}_{1} \times \mathrm{b}_{1}\right)$. The results show an indirect effect of 0.103 and a total effect of 0.504. In addition, the values of $R^{2}$ are observed, of 0.075 for the $\mathrm{BI}$ and 0.255 for the $\mathrm{BR}$, these values present a small increase for the BI and a slight decrease for the BR, with respect to the original model.

\section{Discussion}

In the context of the literature on consumer behavior and service marketing, the study focuses on understanding the determining factors in customer satisfaction and the total perception of quality (image and reputation) of restaurants located in an emerging economy with a high global competitiveness (Kotler et al., 2016; Namin, 2017; Zhu et al., 2018). This answers the objective and the questions designed in the investigation. In this section, we discuss our main findings in the context of the theory of Consumer behavior and Service Marketing. First, we have revealed that the quality of the service perceived by consumers has a strong influence on the valuation of the image of franchise-type restaurants. These results are in the same direction as the theory of the consumer behavior and service marketing, which states that companies that focus their efforts on improving their tangible and intangible assets, adding value to the final delivery of the service to fully satisfy the client, manage to strengthen their image and increase their level of profitability (Dubey et al., 2018; Kotler et al., 2016; Ndubisi et al., 2014; Rungtusanatham et al., 2003). The factors that consumers value most to evaluate the quality of service of restaurants in order of importance are: assurance, empathy, tangibility, responsiveness, and reliability. Similarly, we found that the business image is a factor that encourages the reputation level in restaurants; that is, the actions that it conducts for the full satisfaction of the consumer have a direct impact on the business reputation. These results are also aligned with what is stated by the main theoretical currents and by the main scholars on the topic of marketing and quality in the service (de Leaniz \& del Bosque Rodríguez, 2016; Dowling, 2000; Fracarolli Nunes \& Lee Park, 2017; Gray \& Balmer, 1998). However, our third finding reveals that the quality of service perceived by consumers of franchise-type restaurants does not exert a significant effect on business reputation; therefore, we do not find empirical support for this relationship. This finding may be due to 
the effect of temporary and ineffective strategies of restaurants that target obtaining short-term results and thus lose ground with strong competitors with better attributes (Fracarolli Nunes \& Lee Park, 2017; Gao, Tang, Wang, \& Yin, 2018; Lee et al., 2018). Furthermore, if we add that the competition has become more acute, with the arrival of more recognized restaurants that have a global presence, the preference and degree of the perception of consumers in terms of reputation is seriously affected (Ahn \& Seo, 2018; Namin, 2017; Vázquez-Martinez et al., 2019). Finally, we find that the age and gender of the consumer do not have a positive or significant influence on the level of service quality of the restaurants.

\section{Conclusion}

In the research, as the central point, we have analyzed the level of service quality perceived by consumers to generate strategies to increase the image level and the perception level of the reputation of restaurants. To comply with the objective and research questions, the results indicate that: (1) franchise-type restaurants are correctly taking advantage of their tangible assets, such as safe and comfortable facilities, the comfort of the place, the delivery fulfillment, and the commitment and knowledge of employees to improve the quality of service (Kang \& James, 2004; Khanam, Siddiqui, \& Talib, 2016); (2) the focus on the quality of service of restaurants has been decisive to raise the image level of the company (Namin, 2017; Nyadzayo \& Khajehzadeh, 2016); and (3) restaurants that use marketing actions that are ineffective, fleeting, and/or fashionably fail to raise the perception level of the quality of service but, above all, fail to increase their reputation among their stakeholders, mainly their customers (consumers ) (Kotler et al., 2016; McWilliams, Parhankangas, Coupet, Welch, \& Barnum, 2016; Quoquab et al., 2017; Sanclemente-Téllez, 2017).

The results of the research have generated important implications for restaurants in the region with the firm purpose of strengthening the perception of consumers regarding the quality of service. (1) It is essential that the managers of these businesses continue to take advantage of all their assets to satisfy the demands of consumers and remain in the market longer (Grönroos \& Gummerus, 2014; Han \& Hyun, 2017; Storbacka et al., 1994). In addition to investing in their facilities, it is recommended that these restaurants adopt strategies based on corporate social responsibility, green marketing, and tools to strengthen full- and long-term relationships with the client (Aagaard, 2016; Koo, Koo, \& Dong-Woo, 2018; Lee et al., 2018; Luo \& Bhattacharya, 2006). (2) It is also important and convenient for restaurant managers to adopt new business models and new technology to compete in global markets (Kiran, 2016; Suwandej, 2015). (3) Restaurant owners and managers must constantly train their human capital and always continually evaluate the consumer's perception of the quality of service provided (Miles \& Van Clieaf, 2017; Nonaka, 2007). In addition, the owners and managers of restaurants should focus on new demands and the different manifestations of the demanding behavior of the new generations of consumers who experience and have contact with a large number of multinational companies, with greater technology and with new models of business based on innovation, which makes them more competitive organizations. In the academic and research field, the study contributes to the literature of the American school led by Parasuraman, Zeithaml, and Berry (1988), where it focuses on the measurement of quality of service through the analysis of consumer behavior, with respect to their expectations (quality products and services) against the value offered by the restaurants (perceived value of the client). The model proposed in the research is a combination between the traditional model (American school) and the Nordic school developed by Grönroos (1984) and perfected by Brady and Cronin (2001), because our study incorporates the perception of corporate quality through the valuation of the image and the reputation of the business. This research exhibits certain limitations; conversely, it opens the door for the development of future lines of research. The first limitation in the work is the use of a single source of information. It is because the data were collected from the subjective perceptions expressed by restaurant consumers, which may bias the results. To minimize this limitation, it is advisable to obtain information from employees and managers to compare the results. Second, the sample has been focused only on captive clients of the restaurant service sector in the city of Guaymas. In the future, to conduct cross-cultural studies, the research can focus on more clients from different sectors and regions related to the service. The last limitation contemplated in the study refers to the statistical analysis used based on the variance; in the future, the use of analysis based on covariance can be considered. Given the importance of quality in the service, image, and business reputation, as strategies to increase the competitiveness of businesses, it is expected that researches will be developed to complement this study by incorporating variables, such as emotional intelligence, e-commerce, networks social, and competitiveness, all in the context of the analysis of consumer behavior.

\section{References}

Aagaard, A. (2016). Sustainable Business. River Publishers. Retrieved from https://books.google.com.mx/books?id=ExvkDAAAQBAJ 
Ahn, J. A., \& Seo, S. (2018). Consumer responses to interactive restaurant self-service technology (IRSST): The role of gadget-loving propensity. International Journal of Hospitality Management, 74, 109-121. https://doi.org/10.1016/J.IJHM.2018.02.020

Alon, I. (2006). Executive insight: evaluating the market size for service franchising in emerging markets. International Journal of Emerging Markets, 1(1), 9-20. https://doi.org/10.1108/17468800610644979

Anker, T. B., Sparks, L., Moutinho, L., \& Grönroos, C. (2015). Consumer dominant value creation. European Journal of Marketing, 49(3/4), 532-560. https://doi.org/10.1108/EJM-09-2013-0518

Ariffin, H. F., Bibon, M. F., \& Abdullah, R. P. S. R. (2012). Restaurant's Atmospheric Elements: What the Customer Wants. Procedia - Social and Behavioral Sciences, 38, 380-387. https://doi.org/10.1016/j.sbspro.2012.03.360

Arnould, E. J., \& Thompson, C. J. (2005). Consumer Culture Theory (CCT): Twenty Years of Research. Journal of Consumer Research, 31(4), 868-882. https://doi.org/10.1086/426626

Ashraf, S., Ilyas, R., Imtiaz, M., \& Ahmad, S. (2018). Impact of Service Quality, Corporate Image and Perceived Value on Brand Loyalty with Presence and Absence of Customer Satisfaction: A Study of four Service Sectors of Pakistan. International Journal of Academic Research in Business and Social Sciences, 8(2). https://doi.org/10.6007/IJARBSS/v8-i2/3885

Balmer, J. M. T., \& Greyser, S. A. (2006). Corporate marketing. European Journal of Marketing, 40(7/8), 730-741. https://doi.org/10.1108/03090560610669964

Barnett, M. L., Jermier, J. M., \& Lafferty, B. A. (2006). Corporate Reputation: The Definitional Landscape. Corporate Reputation Review, 9(1), 26-38. https://doi.org/10.1057/palgrave.crr.1550012

Barroso, C., Carrión, G. C., \& Roldán, J. L. (2010). Applying Maximum Likelihood and PLS on Different Sample Sizes: Studies on SERVQUAL Model and Employee Behavior Model. In Handbook of Partial Least Squares (pp. 427-447). Berlin, Heidelberg: Springer Berlin Heidelberg. https://doi.org/10.1007/978-3-540-32827-8_20

Brady, M. K., \& Cronin, J. J. (2001). Some New Thoughts on Conceptualizing Perceived Service Quality: A Hierarchical Approach. Journal of Marketing, 65(3), 34-49. https://doi.org/10.1509/jmkg.65.3.34.18334

Cano, L., Molina Morejon, V., \& Corona-Sandoval, E. (2018). La satisfacción del cliente basada en la calidad del servicio a través de la eficiencia del personal y eficiencia del servicio: un estudio empírico de la industria restaurantera. Revista de Estudios En Contaduría, Administración e Informática, 7(Enero-Abril), 46-65.

Carrión, G. C., Nitzl, C., \& Roldán, J. L. (2017). Mediation Analyses in Partial Least Squares Structural Equation Modeling: Guidelines and Empirical Examples. In Partial Least Squares Path Modeling (pp. 173-195). Cham: Springer International Publishing. https://doi.org/10.1007/978-3-319-64069-3_8

Chen, S.-C. (2015). Customer value and customer loyalty: Is competition a missing link? Journal of Retailing and Consumer Services, 22, 107-116. https://doi.org/10.1016/j.jretconser.2014.10.007

Chen, S. C., \& Elston, J. A. (2013). Entrepreneurial motives and characteristics: An analysis of small restaurant owners. International Journal of Hospitality Management, 35, 294-305. https://doi.org/10.1016/j.ijhm.2013.07.002

Chin, W. W., \& Dibbern, J. (2010). Handbook of Partial Least Squares. https://doi.org/10.1007/978-3-540-32827-8

Chun, R. (2005). Corporate reputation: Meaning and measurement. International Journal of Management Reviews, 7(2), 91-109. https://doi.org/10.1111/j.1468-2370.2005.00109.x

Cronbach, L. J. (1951). Coefficient alpha and the internal structure of tests. Psychometrika, 16(3), 297-334. https://doi.org/10.1007/BF02310555

Cronin, J. J., \& Taylor, S. A. (1992). Measuring Service Quality: A Reexamination and Extension. Journal of Marketing, 56(3), 55. https://doi.org/10.2307/1252296

Curley, M., \& Salmelin, B. (2018). The Evolution of Innovation (pp. 39-45). Springer, Cham. https://doi.org/10.1007/978-3-319-62878-3_4

de Leaniz, P. M. G., \& del Bosque Rodríguez, I. R. (2016). Corporate Image and Reputation as Drivers of Customer Loyalty. Corporate Reputation Review, 19(2), 166-178. https://doi.org/10.1057/crr.2016.2

Deming, W. E. (2000). The new economics: for industry, government, education. MIT Press. 
Deming, W. E., \& Orsini, J. N. (2013). The essential Deming: leadership principles from the father of quality. McGraw-Hill.

Dowling, G. (2000). Creating Corporate Reputations: Identity, Image and Performance. OUP Oxford. Retrieved from https://books.google.es/books?id=bXtS1HGKqa0C

Drucker, P. (2012). Managing in the Next Society. Taylor \& Francis. https://doi.org/10.4324/9780080496283

Dubey, R., Gunasekaran, A., Childe, S. J., Papadopoulos, T., Hazen, B. T., \& Roubaud, D. (2018). Examining top management commitment to TQM diffusion using institutional and upper echelon theories. International Journal of Production Research, 56(8), 2988-3006. https://doi.org/10.1080/00207543.2017.1394590

Elsäßer, M., \& Wirtz, B. W. (2017). Rational and emotional factors of customer satisfaction and brand loyalty in a business-to-business setting. Journal of Business \& Industrial Marketing, 32(1), 138-152. https://doi.org/10.1108/JBIM-05-2015-0101

Erkmen, E., \& Hancer, M. (2019). Building brand relationship for restaurants. International Journal of Contemporary Hospitality Management, 31(3), 1469-1487. https://doi.org/10.1108/IJCHM-08-2017-0516

Escrig-Tena, A. B., Garcia-Juan, B., \& Segarra-Ciprés, M. (2019). Drivers and internalisation of the EFQM excellence model. International Journal of Quality \& Reliability Management, 36(3), 398-419. https://doi.org/10.1108/IJQRM-08-2017-0161

Estrin, S., Nielsen, B. B., \& Nielsen, S. (2017). Emerging Market Multinational Companies and Internationalization: The Role of Home Country Urbanization. Journal of International Management, 23(3), 326-339. https://doi.org/10.1016/J.INTMAN.2016.11.006

Flores, C., Castillo, R., \& Rodríguez, M. D. L. (2013). La importancia del sector servicios en la economía mexicana: un análisis de series de tiempo. Paradigma Económico, 5-27.

Foroudi, P. (2019). Influence of brand signature, brand awareness, brand attitude, brand reputation on hotel industry's brand performance. International Journal of Hospitality Management, 76, 271-285. https://doi.org/10.1016/J.IJHM.2018.05.016

Fracarolli Nunes, M., \& Lee Park, C. (2017). Self-claimed sustainability: Building social and environmental reputations with words. Sustainable Production and Consumption, 11, 46-57. https://doi.org/10.1016/J.SPC.2016.04.002

French, J. (2015). The Importance of Social Marketing History. Social Marketing Quarterly, 21(4), 191-193. https://doi.org/10.1177/1524500415615007

Fukey, L. N., Issac, S. S., Balasubramanian, K., \& Jaykumar, V. (2014). Service Delivery Quality Improvement Models: A Review. Procedia - Social and Behavioral Sciences, 144, 343-359. https://doi.org/10.1016/j.sbspro.2014.07.304

Gao, S., Tang, O., Wang, H., \& Yin, P. (2018). Identifying competitors through comparative relation mining of online reviews in the restaurant industry. International Journal of Hospitality Management, 71, 19-32. https://doi.org/10.1016/J.IJHM.2017.09.004

Gliem, J. A., \& Gliem, R. R. (2003). Calculating, Interpreting, and Reporting Cronbach's Alpha Reliability Coefficient for Likert-Type Scales. Retrieved from https://scholarworks.iupui.edu/handle/1805/344

Goldstein, S. M., Johnston, R., Duffy, J., \& Rao, J. (2002). The service concept: the missing link in service design research? Journal of Operations Management, 20(2), 121-134. https://doi.org/10.1016/S0272-6963(01)00090-0

Gotsi, M., \& Wilson, A. M. (2001). Corporate reputation: seeking a definition. Corporate Communications: An International Journal, 6(1), 24-30. https://doi.org/10.1108/13563280110381189

Gray, E. R., \& Balmer, J. M. T. (1998). Managing Corporate Image and Corporate Reputation. Long Range Planning, 31(5), 695-702. https://doi.org/10.1016/S0024-6301(98)00074-0

Grönroos, C. (1984). A Service Quality Model and its Marketing Implications. European Journal of Marketing, 18(4), 36-44. https://doi.org/10.1108/EUM0000000004784

Grönroos, C., \& Gummerus, J. (2014). The service revolution and its marketing implications: service logic vs service-dominant logic. Managing Service Quality: An International Journal, 24(3), 206-229. https://doi.org/10.1108/MSQ-03-2014-0042

Hackman, J. R., \& Wageman, R. (1995). Total Quality Management: Empirical, Conceptual, and Practical Issues. 
Administrative Science Quarterly, 40(2), 309. https://doi.org/10.2307/2393640

Hair, J. F. (2010). Multivariate data analysis: a global perspective. Pearson Education. Retrieved from https://books.google.com.mx/books?id=SLRPLgAACAAJ\&dq=multivariante+Joseph+hair+2010\&hl=es\&s $\mathrm{a}=$ X\&ved=0ahUKEwiKoMu2kprhAhW7CTQIHa8OBjAQ6AEILDAB

Hair, J. F. (2016). A primer on partial least squares structural equation modeling (PLS-SEM). Retrieved from https://books.google.es/books?id=Xn-LCwAAQBAJ\&dq=SEM+VARIABLES+HENSELER+2017\&lr=\&h $\mathrm{l}=\mathrm{es} \&$ source $=$ gbs_navlinks_s

Hair, J. F., Hult, G. T. M., Ringle, C. M., Sarstedt, M., \& Thiele, K. O. (2017). Mirror, mirror on the wall: a comparative evaluation of composite-based structural equation modeling methods. Journal of the Academy of Marketing Science, 45(5), 616-632. https://doi.org/10.1007/s11747-017-0517-x

Hair, J. F., Sarstedt, M., Hopkins, L., \& Kuppelwieser, V. G. (2014). Partial least squares structural equation modeling (PLS-SEM): An emerging tool in business research. European Business Review, 26(2), 106-121. https://doi.org/10.1108/EBR-10-2013-0128

Han, H., \& Hyun, S. S. (2017). Impact of hotel-restaurant image and quality of physical-environment, service, and food on satisfaction and intention. International Journal of Hospitality Management, 63, 82-92. https://doi.org/10.1016/J.IJHM.2017.03.006

Han, S. H., Nguyen, B., \& Lee, T. J. (2015). Consumer-based chain restaurant brand equity, brand reputation, and brand trust. International Journal of Hospitality Management, 50, 84-93. https://doi.org/10.1016/j.ijhm.2015.06.010

Hayes, A. F., \& Scharkow, M. (2013). The Relative Trustworthiness of Inferential Tests of the Indirect Effect in Statistical Mediation Analysis. Psychological Science, 24(10), 1918-1927. https://doi.org/10.1177/0956797613480187

Heinberg, M., Ozkaya, H. E., \& Taube, M. (2018a). Do corporate image and reputation drive brand equity in India and China? - Similarities and differences. Journal of Business Research, 86, 259-268. https://doi.org/10.1016/j.jbusres.2017.09.018

Heinberg, M., Ozkaya, H. E., \& Taube, M. (2018b). Do corporate image and reputation drive brand equity in India and China? - Similarities and differences. Journal of Business Research, 86, 259-268. https://doi.org/10.1016/j.jbusres.2017.09.018

Holbrook, M. B., \& Hirschman, E. C. (1982). The Experiential Aspects of Consumption: Consumer Fantasies, Feelings, and Fun. Journal of Consumer Research, 9(2), 132. https://doi.org/10.1086/208906

Iglesias, O., Markovic, S., Singh, J. J., \& Sierra, V. (2019). Do Customer Perceptions of Corporate Services Brand Ethicality Improve Brand Equity? Considering the Roles of Brand Heritage, Brand Image, and Recognition Benefits. Journal of Business Ethics, 154(2), 441-459. https://doi.org/10.1007/s10551-017-3455-0

Inkeles, A. (2017). National Character. Routledge. https://doi.org/10.4324/9781315125053

Jayanti, R. K., \& Rajeev Gowda, M. V. (2014). Sustainability dilemmas in emerging economies. IIMB Management Review, 26(2), 130-142. https://doi.org/10.1016/j.iimb.2014.03.004

Jogaratnam, G. (2017). How organizational culture influences market orientation and business performance in the restaurant industry. Journal of Hospitality and Tourism Management, 31, 211-219. https://doi.org/10.1016/j.jhtm.2017.03.002

Joseph, F., Hair, Jr., Marko, S., Christian, M., \& Ringle, S. P. G. (2017). Advanced Issues in Partial Least Squares Structural Equation Modeling (SAGE, Ed.). SAGE. Retrieved from https://books.google.com.mx/books?hl=es\&lr=\&id=-flrDgAAQBAJ\&oi=fnd\&pg=PP1\&dq=Hair+et+al +20 16+VIF,+multicollinearity+PLS\&ots=vX_5koFV9Z\&sig=vtagongb9FZRoAU49ZEochmq8AY\#v=onepage $\& \mathrm{q} \& \mathrm{f}=$ false

Kang, G., \& James, J. (2004). Service quality dimensions: an examination of Grönroos's service quality model. Managing Service Quality: An International Journal, 14(4), 266-277. https://doi.org/10.1108/09604520410546806

Khalique, M., Isa, A., Shaari, N., Abdul, J., \& Ageel, A. (2011). Challenges faced by the small and medium enterprises (SMEs) in Malaysia: An intellectual capital perspective. International Journal of Current Resarch, 3(6), 398-401. 
Khan, M. A. (2014). Restaurant Franchising. Apple Academic Press. https://doi.org/10.1201/b17544

Khanam, S., Siddiqui, J., \& Talib, F. (2016, January 30). Role of Information Technology in Total Quality Management: A Literature Review. Retrieved from https://papers.ssrn.com/sol3/papers.cfm?abstract_id $=2725096$

Kim, B., Kim, \& Byoungsoo. (2018). The Role of Dedication-Based and Constraint-Based Mechanisms in Consumers' Sustainable Outcomes in the Coffee Chain Industry. Sustainability, 10(8), 26-36. https://doi.org/10.3390/su10082636

Kim, E., Tang, L. (Rebecca), \& Bosselman, R. (2018). Measuring customer perceptions of restaurant innovativeness: Developing and validating a scale. International Journal of Hospitality Management, 74, 85-98. https://doi.org/10.1016/j.ijhm.2018.02.018

Kiran, D. R. (2016). Total Quality Management: Key Concepts and Case Studies. https://doi.org/10.1016/B978-0-12-811035-5.00001-5

Koo, D.-W., Koo, \& Dong-Woo. (2018). The Impact of Risk Perceptions of Food Ingredients on the Restaurant Industry: Focused on the Moderating Role of Corporate Social Responsibility. Sustainability, 10(9), 3132. https://doi.org/10.3390/su10093132

Kotler, P., Armstrong, G., Gary, M., \& Parment, A. (2016). Principles of marketing. Retrieved from https://books.google.com.mx/books?id=DWcrjgEACAAJ\&dq=Kotler+and+Armstrong+2016,\&hl=es\&sa= X\&ved=0ahUKEwiAioDxu6feAhVMIDQIHfC6B6IQ6AEIKTAA

Ladeur, K.-H. (2017). Public governance in the age of globalization. Retrieved from https://books.google.com.mx/books?id=AAskDwAAQBAJ\&dq=immigration+problems + of + the+governme $\mathrm{nt}+$ and + globalization $+2017 \& \mathrm{lr}=\& \mathrm{hl}=$ es\&source $=$ gbs_navlinks_s

Lanchimba, C., \& Medina, D. (2018). Impacto del franquiciamiento en el desarrollo. Problemas Del Desarrollo. $\begin{array}{llll}\text { Revista Latinoamericana de } & \text { Economía, 49-118. }\end{array}$ https://doi.org/10.22201/iiec.20078951e.2018.193.61283

Lee, S. Y., Lim, E. R., \& Drumwright, M. E. (2018). Hybrid happening: Organizational reputations in corporate crises. Public Relations Review, 44(4), 598-609. https://doi.org/10.1016/j.pubrev.2018.05.008

Luo, X., \& Bhattacharya, C. B. (2006). Corporate Social Responsibility, Customer and Satisfaction, and Market Value. Journal of Marketing, 70(4), 1-18. https://doi.org/10.1509/jmkg.70.4.1

Lusch, R. F., Vargo, S. L., Bolton, R. N., \& Webster, F. E. (2014). The service-dominant logic of marketing: dialog, debate, and directions.

Madanoglu, M., Alon, I., \& Shoham, A. (2017). Push and pull factors in international franchising. International Marketing Review, 34(1), 29-45. https://doi.org/10.1108/IMR-03-2015-0037

Madanoglu, M., Erdem, M., \& Gursoy, D. (2008). Risk return and cost of equity of small and large casual-dining restaurants. International Journal of Hospitality Management, 27(1), 109-118. https://doi.org/10.1016/j.ijhm.2007.07.006

Martínez, J. A., \& Martínez, L. (2010). Some insights on conceptualizing and measuring service quality. Journal of Retailing and Consumer Services, 17(1), 29-42. https://doi.org/10.1016/j.jretconser.2009.09.002

McKenzie-Mohr, D., \& Schultz, P. W. (2014). Choosing Effective Behavior Change Tools. Social Marketing Quarterly, 20(1), 35-46. https://doi.org/10.1177/1524500413519257

McWilliams, A., Parhankangas, A., Coupet, J., Welch, E., \& Barnum, D. T. (2016). Strategic Decision Making for the Triple Bottom Line. Business Strategy and the Environment, 25(3), 193-204. https://doi.org/10.1002/bse.1867

Melewar, T. C., Foroudi, P., Gupta, S., Kitchen, P. J., \& Foroudi, M. M. (2017). Integrating identity, strategy and communications for trust, loyalty and commitment. European Journal of Marketing, 51(3), 572-604. https://doi.org/10.1108/EJM-08-2015-0616

Miles, S. J., \& Van Clieaf, M. (2017). Strategic fit: Key to growing enterprise value through organizational capital. Business Horizons, 60(1), 55-65. https://doi.org/10.1016/j.bushor.2016.08.008

Namin, A. (2017). Revisiting customers' perception of service quality in fast food restaurants. Journal of Retailing and Consumer Services, 34, 70-81. https://doi.org/10.1016/j.jretconser.2016.09.008

Ndubisi, N. O., Nataraajan, R., \& Lai, R. (2014). Customer perception and response to ethical norms in legal 
services marketing. Journal of Business Research, 67(3), 369-377. https://doi.org/10.1016/j.jbusres.2013.01.001

Nguyen, N., \& Leblanc, G. (2001). Corporate image and corporate reputation in customers' retention decisions in services. Journal of Retailing and Consumer Services, 8(4), 227-236. https://doi.org/10.1016/S0969-6989(00)00029-1

Nitzl, C., Roldan, J. L., \& Cepeda, G. (2016). Mediation analysis in partial least squares path modeling. Industrial Management \& Data Systems, 116(9), 1849-1864. https://doi.org/10.1108/IMDS-07-2015-0302

Nonaka, I. (2007). The knowledge-creating company. Harvard Business Review, 85(7-8). https://doi.org/10.1016/0024-6301(96)81509-3

Nwachukv, S., Vitell, S., Gilbert, F., \& Barnes, J. (1997). Ethics and social responsibility in marketing: An examination of the ethics evaluation of advertising strategies. Journal of Business Research, 39(2), 107-188. https://doi.org/10.1016/S0148-2963(96)00146-4

Nyadzayo, M. W., \& Khajehzadeh, S. (2016). The antecedents of customer loyalty: A moderated mediation model of customer relationship management quality and brand image. Journal of Retailing and Consumer Services, 30, 262-270. https://doi.org/10.1016/j.jretconser.2016.02.002

OECD. (2017). Organisation for Economic Co-operation and Development. Small, medium, strong. Trends in SME performance and business conditions. Retrieved from https://books.google.es/books?id=OKpmtAEACAAJ\&dq=OECD,+development+economics + employee + in + the + SMEs $+2017 \& \mathrm{hl}=$ es\&sa $=$ X\&ved $=0$ ahUKEwjy1YTXov3aAhVE6xQKHYrTCM0Q6AEITzAF

Oliver, R. L. (2014). Satisfaction: A Behavioral Perspective on the Consumer. Routledge. https://doi.org/10.4324/9781315700892

Palmatier, R. W., Dant, R. P., Grewal, D., \& Evans, K. R. (2006). Factors Influencing the Effectiveness of Relationship Marketing: A Meta-Analysis. Journal of Marketing, 70(4), 136-153. https://doi.org/10.1509/jmkg.70.4.136

Parasuraman, A., Zeithaml, V. A., \& Berry, L. L. (1988). Servqual: A multiple-item scale for measuring consumer perc. Journal of Retailing, 64(1), 12.

Parasuraman, A., Zeithaml, V. A., \& Berry, L. L. (1998). Alternative Scales for Measuring Service Quality: A Comparative Assessment Based on Psychometric and Diagnostic Criteria. In Handbuch Dienstleistungsmanagement (pp. 449-482). Wiesbaden: Gabler Verlag. https://doi.org/10.1007/978-3-322-96503-5_19

Peterson, R. A. (1994). A Meta-Analysis of Cronbach's Coefficient Alpha. Journal of Consumer Research, 21(2), 381. https://doi.org/10.1086/209405

Quoquab, F., Thurasamy, R., \& Mohammad, J. (2017). Driving green consumerism through strategic sustainability marketing. https://doi.org/10.4018/978-1-5225-2912-5

Reio, T. G. (2010). The Threat of Common Method Variance Bias to Theory Building. Human Resource Development Review, 9(4), 405-411. https://doi.org/10.1177/1534484310380331

Rungtusanatham, M., Ogden, J. A., \& Wu, B. (2003). Advancing theory development in total quality management. International Journal of Operations \& Production Management, 23(8), 918-936. https://doi.org/10.1108/01443570310486356

Sánchez-Fernández, R., Iniesta-Bonillo, M. Á., \& Holbrook, M. B. (2018). The Conceptualisation and Measurement of Consumer Value in Services. https://doi.org/10.1177/147078530905100108

Sanchez-Franco, M. J., Cepeda-Carrion, G., \& Roldán, J. L. (2019). Understanding relationship quality in hospitality services. Internet Research, 29(3), 478-503. https://doi.org/10.1108/IntR-12-2017-0531

Sanclemente-Téllez, J. C. (2017). Marketing and Corporate Social Responsibility (CSR). Moving between broadening the concept of marketing and social factors as a marketing strategy. Spanish Journal of Marketing - ESIC, 21, 4-25. https://doi.org/10.1016/j.sjme.2017.05.001

Sarstedt, M., Ringle, C. M., \& Hair, J. F. (2017). Partial Least Squares Structural Equation Modeling. In Handbook of Market Research (pp. 1-40). Cham: Springer International Publishing. https://doi.org/10.1007/978-3-319-05542-8_15-1

Song, S., Park, S., \& Lee, S. (2017). Impacts of geographic diversification on restaurant firms' risk: Domestic vs. 
international diversification. International Journal of Hospitality Management, 61, 107-118. https://doi.org/10.1016/j.ijhm.2016.11.011

Spence, L. J. (2016). Small Business Social Responsibility. Business \& Society, 55(1), 23-55. https://doi.org/10.1177/0007650314523256

Storbacka, K., Strandvik, T., \& Grönroos, C. (1994). Managing Customer Relationships for Profit: The Dynamics of Relationship Quality. International Journal of Service Industry Management, 5(5), 21-38. https://doi.org/10.1108/09564239410074358

Sun, K.-A., Park, S., \& He, Z. (2019). Effect of franchising on restaurant firms' risk evaluations in the bond market. International Journal of Hospitality Management, 83, 19-27. https://doi.org/10.1016/j.ijhm.2019.03.021

Susanti, C. E. (2013). The Effect of Product Quality and Service Quality Towards Customer Satisfaction and Customer Loyalty in Traditional Restaurants in East Java (pp. 383-393). In Proceedings of the International Conference on Managing the Asian Century. Singapore: Springer Singapore. https://doi.org/10.1007/978-981-4560-61-0_43

Suwandej, N. (2015). Factors Influencing Total Quality Management. Procedia - Social and Behavioral Sciences, 197, 2215-2222. https://doi.org/10.1016/j.sbspro.2015.07.361

Teece, D. J. (2010). Business models, business strategy and innovation. Long Range Planning, 43(2-3), 172-194. https://doi.org/10.1016/j.lrp.2009.07.003

Thai, V. V., Tay, W. J., Tan, R., \& Lai, A. (2014). Defining Service Quality in Tramp Shipping: Conceptual Model and Empirical Evidence. The Asian Journal of Shipping and Logistics, 30(1), 1-29. https://doi.org/10.1016/j.ajsl.2014.04.001

Tsai, C.-T. (Simon), \& Wang, Y.-C. (2017). Experiential value in branding food tourism. Journal of Destination Marketing \& Management, 6(1), 56-65. https://doi.org/10.1016/j.jdmm.2016.02.003

van den Bosch, A. L. M., Elving, W. J. L., \& de Jong, M. D. T. (2006). The impact of organisational characteristics on corporate visual identity. European Journal of Marketing, 40(7/8), 870-885. https://doi.org/10.1108/03090560610670034

van Doorn, J., Lemon, K. N., Mittal, V., Nass, S., Pick, D., Pirner, P., \& Verhoef, P. C. (2010). Customer Engagement Behavior: Theoretical Foundations and Research Directions. Journal of Service Research, 13(3), 253-266. https://doi.org/10.1177/1094670510375599

Vargo, S. L., Lusch, R. F., \& Lusch, R. F. (2014). Evolving to a New Dominant Logic for Marketing (pp. 21-46). https://doi.org/10.4324/9781315699035-9

Vázquez-Martinez, U. J., Sanchís-Pedregosa, C., Leal-Rodríguez, A. L., Vázquez-Martinez, U. J., Sanchís-Pedregosa, C., \& Leal-Rodríguez, A. L. (2019). Is Gastronomy A Relevant Factor for Sustainable Tourism? An Empirical Analysis of Spain Country Brand. Sustainability, 11(9), 2696. https://doi.org/10.3390/su11092696

Veloutsou, C., \& Delgado-Ballester, E. (2018). New challenges in brand management. Spanish Journal of Marketing - ESIC, 22(3), 254-271. https://doi.org/10.1108/SJME-12-2018-036

Villegas-Malagón, M. B., Reyes-Martínez, Reyes, E. Y., García, V. M., Garcia, J. J., \& Pérez-Mora, J. C. (2017). Diagnóstico y propuesta estratégica de atención y servicio al cliente en restaurantes de la ciudad de Hidalgo. Michoacan, 39(126), 385-395.

Waheed, A., Abbas, Q., Malik, O., Waheed, A., Abbas, Q., \& Malik, O. F. (2018). 'Perceptions of Performance Appraisal Quality' and Employee Innovative Behavior: Do Psychological Empowerment and 'Perceptions of HRM System Strength' Matter? Behavioral Sciences, 8(12), 114. https://doi.org/10.3390/bs8120114

Wallin, A. T., \& Lindestad, B. (1998). Customer loyalty and complex services. International Journal of Service Industry Management, 9(1), 7-23. https://doi.org/10.1108/09564239810199923

Walls, A. R., Okumus, F., Wang, Y. R., \& Kwun, D. J.-W. (2011). An epistemological view of consumer experiences. International Journal of Hospitality Management, 30(1), 10-21. https://doi.org/10.1016/j.ijhm.2010.03.008

Walsh, G., Beatty, S. E., \& Shiu, E. M. K. (2009). The customer-based corporate reputation scale: Replication and short form. Journal of Business Research, 62(10), 924-930. https://doi.org/10.1016/j.jbusres.2007.11.018

Wang, C., Hoegg, J., \& Dahl, D. W. (2018). The impact of a sales team's perceived entitativity on customer 
satisfaction. Journal of the Academy of Marketing Science, 46(2), 190-211. https://doi.org/10.1007/s11747-017-0573-2

Wang, Y. D., \& Emurian, H. H. (2005). An overview of online trust: Concepts, elements, and implications. Computers in Human Behavior, 21(1), 105-125. https://doi.org/10.1016/j.chb.2003.11.008

Williams, J. (1998). The Challenges That Face Restaurants in Attracting and Meeting the Needs of the Mature Customer. Journal of Restaurant \& Foodservice Marketing, 2(4), 49-64. https://doi.org/10.1300/J061v02n04_04

Williams, J., \& MacKinnon, D. P. (2008). Resampling and Distribution of the Product Methods for Testing Indirect Effects in Complex Models. Structural Equation Modeling: A Multidisciplinary Journal, 15(1), 23-51. https://doi.org/10.1080/10705510701758166

Wu, H.-C., Cheng, C.-C., Ai, C.-H., \& Chen, G. (2019). Relationships between restaurant attachment, experiential relationship quality and experiential relationship intentions: The case of single friendly restaurants in Taiwan. Journal of Hospitality and Tourism Management, 40, 50-66. https://doi.org/10.1016/j.jhtm.2019.06.002

Yaman, Z. (2018). The Effect of Word of Mouth Marketıng on the Purchase Behavior Via Brand Image and Perceived Quality. Montenegrin Journal of Economics, 14(2), 175-182. https://doi.org/10.14254/1800-5845/2018.14-2.12

Yi, Z. G. (2018a). Marketing services and resources in information organizations. Chandos Publishing. Retrieved from

https://books.google.com.mx/books?id=tuaMCgAAQBAJ\&dq=marketing+services\&hl=es\&source=gbs_na vlinks_s

Yi, Z. G. (2018b). Marketing services and resources in information organizations. Chandos Publishing. Retrieved from https://books.google.com.mx/books?id=tuaMCgAAQBAJ\&dq=marketing+services, + Kotler+2014\&hl=es\& source $=$ gbs_navlinks_s

Zahra, S. A., \& Wright, M. (2011). Entrepreneurship's Next Act. Academy of Management Perspectives, 25(4), 67-83. https://doi.org/10.5465/amp.2010.0149

Zhang, T., Chen, J., Hu, B., Zhang, T., Chen, J., \& Hu, B. (2019). Authenticity, Quality, and Loyalty: Local Food and Sustainable Tourism Experience. Sustainability, 11(12), 3437. https://doi.org/10.3390/su11123437

Zhang, Y. (2015). The Impact of Brand Image on Consumer Behavior: A Literature Review. Open Journal of Business and Management, 03(01), 58-62. https://doi.org/10.4236/ojbm.2015.31006

Zhu, Y., Freeman, S., \& Cavusgil, S. T. (2018). Service quality delivery in a cross-national context. International Business Review, 27(5), 1022-1032. https://doi.org/10.1016/j.ibusrev.2018.03.002

\section{Note}

This project received funding for its development and publication by the Program for Strengthening Educational Quality (PFCE, 2018) of the Secretariat of Public Education of Mexico.

\section{Copyrights}

Copyright for this article is retained by the author, with first publication rights granted to the journal.

This is an open-access article distributed under the terms and conditions of the Creative Commons Attribution license (http://creativecommons.org/licenses/by/4.0/). 